\title{
Syntheses, characterization and crystal structures of copper(I) $o$-(diphenylphosphino)benzaldehyde complexes
}

\author{
Wen-Yann Yeh ${ }^{\mathrm{a}, *}$, Yu-Chiao Liu ${ }^{\mathrm{a}}$, Shie-Ming Peng ${ }^{\mathrm{b}}$, Gene-Hsiang Lee ${ }^{\mathrm{b}}$ \\ a Department of Chemistry, National Sun Yat-Sen University, Kaohsiung 804, Taiwan \\ b Department of Chemistry, National Taiwan University, Taipei 106, Taiwan
}

Received 8 November 2004; accepted 30 December 2004

\begin{abstract}
The complexes $\left[\mathrm{Cu}(\mathrm{PCHO})_{2}(\mathrm{NCMe})\left[\mathrm{BF}_{4}\right](\mathbf{1})\right.$ and $\left[\mathrm{Cu}(\mathrm{PCHO})_{3}\right]\left[\mathrm{BF}_{4}\right](\mathbf{2})$ have been prepared by treating $\left[\mathrm{Cu}(\mathrm{NCMe})_{4}\right]\left[\mathrm{BF}{ }_{4}\right]$ with two and three equivalents of $\mathrm{Ph}_{2} \mathrm{P}\left(o-\mathrm{C}_{6} \mathrm{H}_{4}\right) \mathrm{C}(=\mathrm{O}) \mathrm{H}$ (abbreviated as $\mathrm{PCHO}$ ) at room temperature, respectively. The reaction of $\mathbf{1}$ and $\left(\mathrm{Ph}_{2} \mathrm{PC}_{5} \mathrm{H}_{4}\right)_{2} \mathrm{Fe}$ (abbreviated as DPPF) affords [Cu(PCHO)(DPPF)][BF 4 (3). The molecular structures of $\mathbf{1}-\mathbf{3}$ have been determined by an X-ray diffraction study. The aldehyde groups in $\mathbf{1}$ are pendant, while one of the formyl groups in $\mathbf{2}$ is weakly coordinated to the copper ion through the oxygen atom. On the other hand, the copper atom in $\mathbf{3}$ is strongly chelated by both DPPF and PCHO ligands. (c) 2005 Elsevier B.V. All rights reserved.
\end{abstract}

Keywords: $\mathrm{Cu}(\mathrm{I})$ complex; $\mathrm{P}-\mathrm{O}$ chelation; $\mathrm{PCHO}$ ligand

\section{Introduction}

The coordination chemistry of copper(I) and copper(II) ions is well established. While copper(II) is generally considered a borderline hard acid, copper(I) clearly behaves as a soft acid. For instance, with $\mathrm{O}, \mathrm{S}$, $\mathrm{N}$ and $\mathrm{P}$ ligands, the $\mathrm{O}$ and $\mathrm{N}$ ligands dominate the chemistry of copper(II), while the $\mathrm{S}$ and $\mathrm{P}$ ligands are more frequent in copper(I) chemistry [1]. Recently, functionalized tertiary phosphines have attracted considerable interest for their unusual coordination chemistry and their increasing importance in catalysis [2]. The $o$ (diphenylphosphino)benzaldehyde molecule (abbreviated as PCHO), which contains a "soft" phosphorus and a "hard" oxygen donor atoms, is one of the simplest bidendate $\mathrm{P}, \mathrm{O}-$ chelating agents [3]. Usually, the phosphine center is coordinated to a metal in advance of the aldehyde group and can serve as a monodentate

\footnotetext{
${ }^{*}$ Corresponding author. Tel.: +88 675252000 3927; fax: +88 675 253908.

E-mail address: wenyann@mail.nsysu.edu.tw (W.-Y. Yeh).
}

$\eta^{1}-\mathrm{P}$ donor in $\mathrm{W}(\mathrm{CO})_{5}(\mathrm{PCHO})[4]$ and $\mathrm{RhCl}(\mathrm{CO})(\mathrm{P}-$ $\mathrm{CHO})_{2}$ [5]. Subsequent oxidative addition of the aldehyde $\mathrm{C}-\mathrm{H}$ bond on a $\mathrm{Rh}(\mathrm{I})$ [6], $\operatorname{Ir}(\mathrm{I})$ [7], $\operatorname{Pt}(0)$ [8], $\mathrm{Co}(\mathrm{I})$ [9], $\mathrm{Pd}(\mathrm{II})$ [10] or $\mathrm{Ru}(\mathrm{II})$ [11] center can generate a phosphine-acyl hydrido complex. On the other hand, the PCHO ligand can act as chelating phosphine-aldehyde with the aldehyde moiety bonded to a metal in a $\sigma$-fashion through the oxygen atom in $\operatorname{Re}(\mathrm{CO})_{3} \mathrm{Cl}(\mathrm{P}$ CHO) [12] and $\mathrm{RuCl}_{2}(\mathrm{PCHO})_{2}$ [13], or in a $\pi$-fashion through the carbon-oxygen double bond in $\mathrm{Cp} * \mathrm{Co}(\mathrm{P}-$ $\mathrm{CHO})$ [14], $\mathrm{W}(\mathrm{CO})_{3}(\mathrm{PCHO})_{2}$ and $\mathrm{W}(\mathrm{CO})_{2}(\mathrm{PCHO})_{2}$ [15]. In this paper, we explore the coordination chemistry of PCHO ligand with $\mathrm{Cu}(\mathrm{I})$ ion to give complexes with/without the chelation of the aldehyde groups.

\section{Results and dissusion}

Reaction of $\left[\mathrm{Cu}(\mathrm{NCMe})_{4}\right]\left[\mathrm{BF}_{4}\right]$ with two equivalents of PCHO in dichloromethane solvent at ambient temperature afforded a yellow solution, from which yellow crystals of $\left[\mathrm{Cu}(\mathrm{PCHO})_{2}(\mathrm{NCMe})\right]\left[\mathrm{BF}_{4}\right](\mathbf{1})$ were obtained 
in $89 \%$ yield after crystallization from $n$-hexane/dichloromethane. Further reaction of $\mathbf{1}$ with equimolar amount of $\mathrm{PCHO}$ in dichloromethane solvent at ambient temperature produced orange-yellow crystals of $\left[\mathrm{Cu}(\mathrm{PCHO})_{3}\right]\left[\mathrm{BF}_{4}\right](\mathbf{2})$ in $92 \%$ yield after crystallization from $n$-hexane/dichloromethane. It was thought that elimination of the acetonitrile ligand from 1 might generate the species, $\left[\mathrm{Cu}(\mathrm{PCHO})_{2}\right]^{+}$, with both PCHO ligands in a P,O-chelating mode. However, heating compound 1 in THF underwent a disproportion reaction to give $\mathbf{2}$ as the only isolable product. On the other hand, reaction of $\mathbf{1}$ with the diphosphine molecule $\left(\mathrm{Ph}_{2} \mathrm{PC}_{5} \mathrm{H}_{4}\right)_{2} \mathrm{Fe}$ (abbreviated as DPPF) led to dissociation of a PCHO ligand to afford orange crystals of $[\mathrm{Cu}(\mathrm{PCHO})(\mathrm{DPPF})]\left[\mathrm{BF}_{4}\right]$ (3) in $56 \%$, in which both DPPF and PCHO act as a chelating ligand. The reactions are summarized in Scheme 1. Previously, the importance of steric constraints in $\left[\mathrm{Cu}\left(\mathrm{PR}_{3}\right)_{3}\right]^{+}$complexes was well established [16], so that the PCHO ligand forming the trigonal complexes $\mathbf{1}$ and $\mathbf{2}$ is likely for steric reasons. Nevertheless, the steric properties of the neutral ligands are not the sole determinations and the electronic properties of the ligands can also affect cation stoichiometry. This is well illustrated by $\mathrm{Cu}(\mathrm{I})$ complexes formed by pyridine, 2-methylpyridine and 4-methylpyridine [17].

Single crystals of 1-3 were grown by diffusion of diethyl ether (for 1) or $n$-hexane (for 2 and 3 ) into a dichloromethane solution of the compound at ambient temperature. The structure of $\mathbf{1}$ consists of discrete cations $\left[\mathrm{Cu}(\mathrm{PCHO})_{2}(\mathrm{NCMe})\right]^{+}$and tetrafluoroborate counter anions. The ORTEP drawing for the complex is depicted in Fig. 1. In contrast to the tetrahedron geometry in $\left[\mathrm{Cu}(\mathrm{NCMe})_{4}\right]^{+}[18]$, the copper atom of 1 is nominally three-coordinate with ligation by an acetonitrile and two PCHO ligands. With the N1, P1 and P2 atoms forming the basal trigonal plane, the interligand bond angles surrounding the $\mathrm{Cu}$ atom are within $7^{\circ}$ of the trigonal expectation of $120^{\circ}$; the three angles sum to $360^{\circ}$, consistent with the small displacement of the $\mathrm{Cu}$ atom from the basal trigonal plane $(0.01 \AA)$. The formyl groups are on opposite sides of the $\mathrm{CuP}_{2} \mathrm{~N}$ plane, with the oxygen atoms oriented toward the copper atom. The two benzaldehyde units are planar, indicating conjugation of $\mathrm{C}=\mathrm{O} \pi$ bond with the aromatic system. The benzaldehyde rings are about parallel with a dihedral angle of $4.8^{\circ}$ and the mean separation of the planes is $3.41 \AA$. This value may be compared with $3.35 \AA$ for

$\left[\mathrm{Cu}(\mathrm{NCMe})_{4}\right]^{+} \mathrm{BF}_{4}^{-}+2 \mathrm{PCHO}$

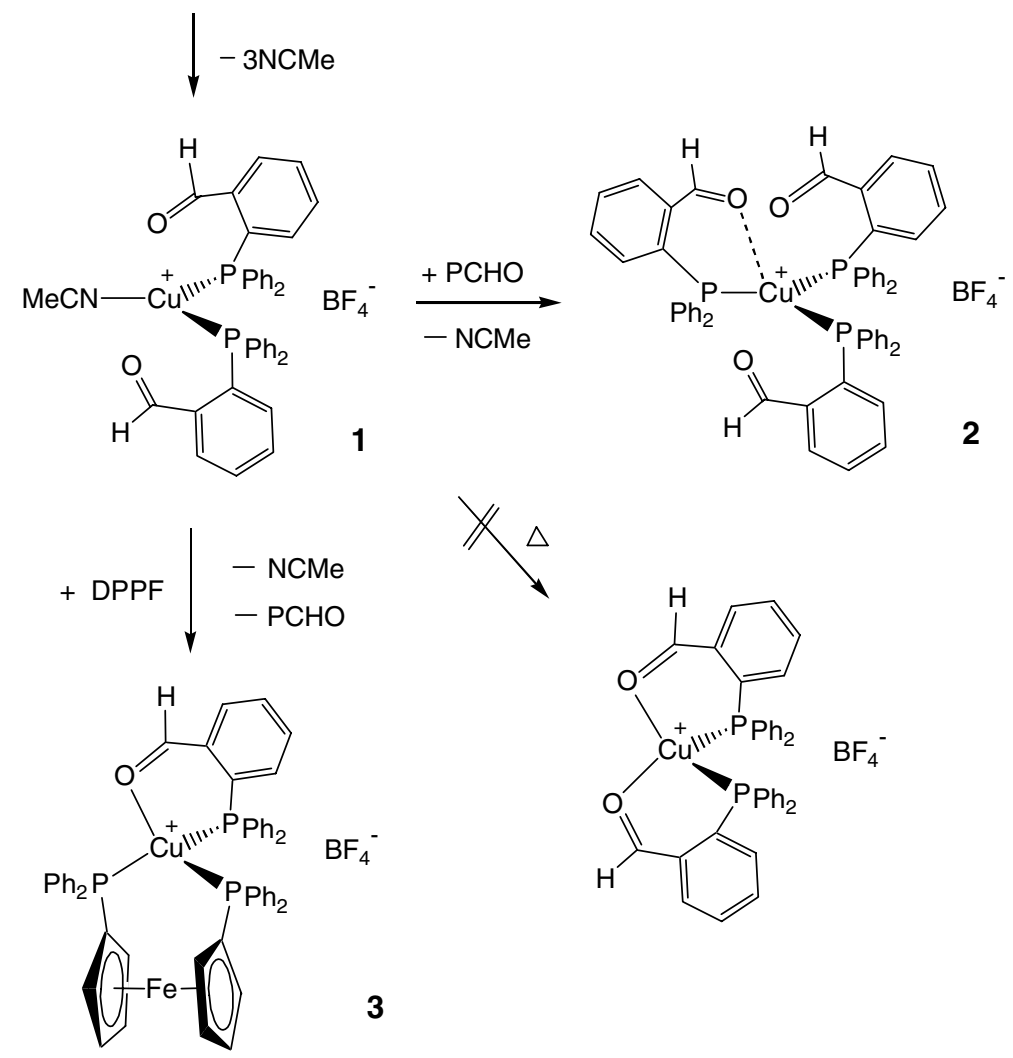




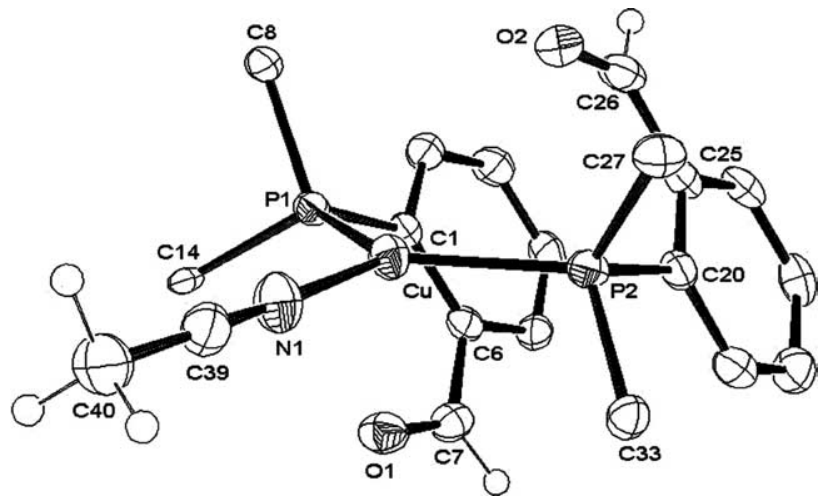

Fig. 1. Molecular structure of $\mathbf{1}$. The $\mathrm{BF}_{4}{ }^{-}$anion has been artificially omitted. Only the ipso carbons of the $\mathrm{C}_{6} \mathrm{H}_{5}$ groups are shown for clarity. Selected bond distances $(\AA)$ and angles $\left({ }^{\circ}\right)$ : $\mathrm{Cu}-\mathrm{P} 12.231(1)$, $\mathrm{Cu}-\mathrm{P} 2$ 2.239(1), Cu-N1 1.954(5), C7-O1 1.218(6), C26-O2 1.217(7), $\mathrm{Cu} \cdots \mathrm{O} 1$ 2.74, $\mathrm{Cu} \cdots \mathrm{O} 2$ 3.23; $\mathrm{P} 1-\mathrm{Cu}-\mathrm{P} 2$ 127.12(5), P1-Cu-N1 118.7(1), P2-Cu-N1 114.1(1), Cu-N1-C39 178.2(5), N1-C39-C40 178.5(6), C25-C26-O2 125.7(5), C6-C7-O1 124.1(5).

the interplane distance in graphite and can be described in terms of a van der Waals type interaction [19].

The structure of 2 consists of discrete cations $[\mathrm{Cu}(\mathrm{P}-$ $\left.\mathrm{CHO})_{3}\right]^{+}$, tetrafluoroborate counter anions and solvent molecules. The ORTEP drawing for the cation is depicted in Fig. 2. The $\mathrm{Cu}^{+}$ion is in a mildly distorted trigonal pyramidal environment with the copper atom lying $0.08 \AA$ above the plane (toward the $\mathrm{O} 3$ atom) of the three phosphorous atoms. The $\mathrm{Cu}-\mathrm{P}$ distances range from $2.297(2)$ to $2.345(2) \AA$, with a mean value of $2.324 \AA$. The mean $\mathrm{P}-\mathrm{Cu}-\mathrm{P}$ bond angle is $119.9^{\circ}$, which is close to the ideal value of $120^{\circ}$. The benzaldehyde groups connected to the $\mathrm{P} 1$ and $\mathrm{P} 2$ atoms are about parallel, with a mean interplane distance of $3.41 \AA$. An unusual feature of the copper center is the long, off-normal bond to the apical O3 atom (2.68(7) $\AA$ ), while the nonbonded $\mathrm{Cu} \cdots \mathrm{O} 1$ and $\mathrm{Cu} \cdots \mathrm{O} 2$ distances are 2.97 and

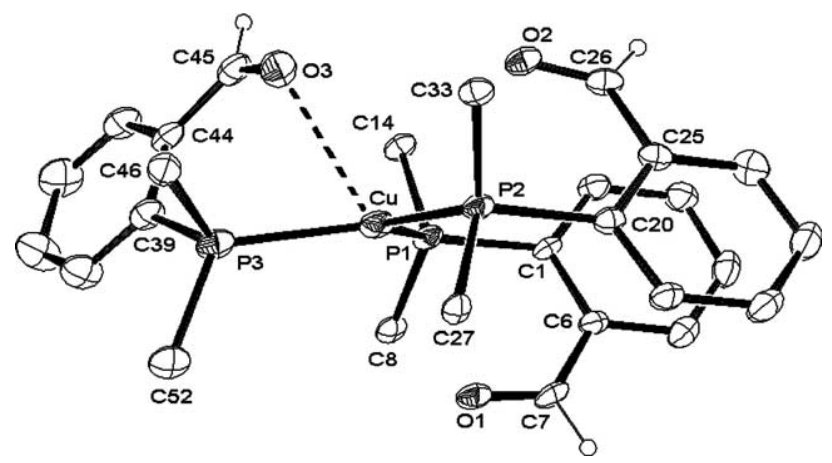

Fig. 2. Molecular structure of 2 . The $\mathrm{BF}_{4}{ }^{-}$anion has been artificially omitted. Only the ipso carbons of the $\mathrm{C}_{6} \mathrm{H}_{5}$ groups are shown for clarity. Selected bond distances $(\AA)$ and angles $\left({ }^{\circ}\right)$ : $\mathrm{Cu}-\mathrm{P} 1$ 2.330(2), Cu-P2 2.297(2), Cu-P3 2.345(2), C7-O1 1.204(8), C26-O2 1.210(8),

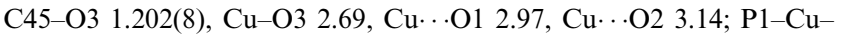
P2 123.56(7), P1-Cu-P3 120.47(7), P2-Cu-P3 115.62(7), C25-C26-O2 125.3(6), C6-C7-O1 126.1(6), C44-C45-O3 125.5(6).
$3.14 \AA$, respectively. The $\mathrm{O} 1-\mathrm{Cu}-\mathrm{P} 1$ angle is very acute, being $68.1(7)^{\circ}$.

The structure of 3 consists of discrete cations $[\mathrm{Cu}(\mathrm{P}-$ $\mathrm{CHO})(\mathrm{DPPF})]^{+}$and tetrafluoroborate counter anions. The ORTEP drawing for the cation is illustrated in Fig. 3. The coordination about the $\mathrm{Cu}^{+}$ion can be described as an irregular tetrahedron. The angles around the copper atom range from $82.90(5)^{\circ}$ for $\mathrm{P} 1-\mathrm{Cu}-\mathrm{O} 1$ to $127.86(2)^{\circ}$ for $\mathrm{P} 1-\mathrm{Cu}-\mathrm{P} 2$. Distortion of the $\mathrm{CuP}_{3}$ configuration is noted with the further displacement of the copper atom to a distance of $0.27 \AA$ above the plane of the three phosphorous atoms. Accompanying the displacement of the copper toward $\mathrm{O} 1$ is the decrease of the mean $\mathrm{P}-\mathrm{Cu}-\mathrm{P}$ bond angles from a value of $119.9^{\circ}$ in 2 to a value of $118.6^{\circ}$ in 3 . The DPPF and PCHO ligands are bidentate, showing a bite angle of $109.31(2)^{\circ}$ and $82.90(5)^{\circ}$, respectively. The two Cp rings of DPPF ligand are about parallel, with a dihedral angle of $2.63^{\circ}$ and a mean interplane distance of $3.30 \AA$. The formyl group is coordinated to the copper atom through the oxygen atom with the $\mathrm{Cu}-\mathrm{O} 1$ length of $2.276(2) \AA$, which is $0.41 \AA$ shorter than the $\mathrm{Cu}-\mathrm{O} 3$ length in $\mathbf{2}$. The benzaldehyde group is not planar, where the $\mathrm{C} 7-$ $\mathrm{O} 1$ vector is tilted $7.60^{\circ}$ away from the ring plane. The $\mathrm{Cu} \cdots \mathrm{Fe}$ distance is $4.12 \AA$, too large a value to support a significant metal-metal interaction.

Compounds 1-3 form stable crystals. The ${ }^{31}\left\{{ }^{1} \mathrm{H}\right\}$ NMR of 1 shows one broad signal at $\delta 0.47$. The ${ }^{1} \mathrm{H}$ NNR spectrum of $\mathbf{1}$ at $25^{\circ} \mathrm{C}$ displays a $2 \mathrm{H}$ singlet at $\delta 9.74$ for the formyl protons, a multiplet in the range $\delta 7.98-7.07$ for the phenyl protons, and a $3 \mathrm{H}$ singlet at $\delta$ 2.12 for the methyl protons. The ${ }^{1} \mathrm{H}$ and ${ }^{31} \mathrm{P}$ resonance patterns essentially remain unchanged down to $-90{ }^{\circ} \mathrm{C}$, in agreement with the structure with a time-averaged $C_{2}$ symmetry in solution.

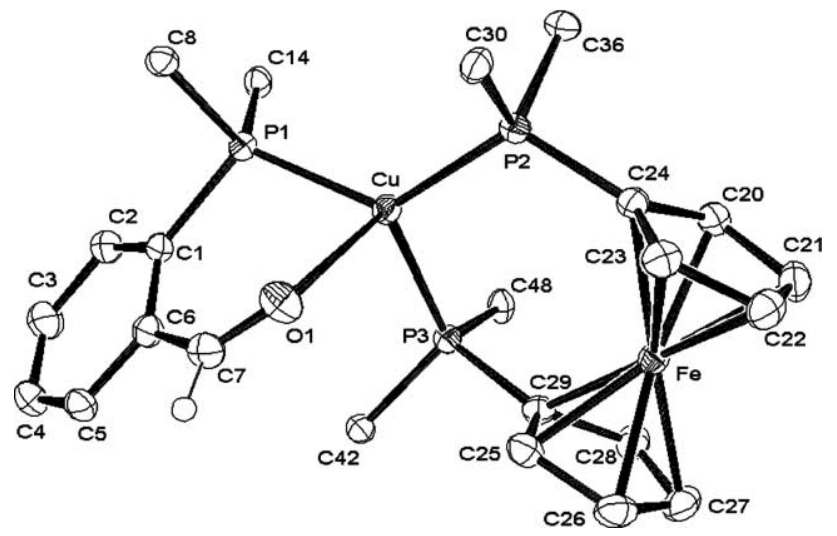

Fig. 3. Molecular structure of 3. The $\mathrm{BF}_{4}{ }^{-}$anion has been artificially omitted. Only the ipso carbons of the $\mathrm{C}_{6} \mathrm{H}_{5}$ groups are shown for clarity. Selected bond distances $(\AA)$ and angles $\left({ }^{\circ}\right)$ : $\mathrm{Cu}-\mathrm{P} 12.2452(6)$, Cu-P2 2.2484(6), Cu-P3 2.2586(6), Cu-O1 2.276(2), C7-O1 1.216(3); P1-Cu-P2 127.86(2), P1-Cu-P3 118.52(2), P2-Cu-P3 109.31(2), P1$\mathrm{Cu}-\mathrm{O} 1$ 82.90(5), P2-Cu-O1 112.04(4), P3-Cu-O1 96.44(5), C6-C7-O1 127.8(2), C7-O1-Cu 126.0(2). 
The ${ }^{1} \mathrm{H}$ NNR spectrum of 2 at $25{ }^{\circ} \mathrm{C}$ presents a $3 \mathrm{H}$ singlet at $\delta 9.17$ for the formyl protons, and a multiplet between $\delta 7.74$ and 6.82 for the phenyl protons. The formyl signal collapses at $-30^{\circ} \mathrm{C}$, and at $-80^{\circ} \mathrm{C}$ splits into three $1 \mathrm{H}$ signals at $\delta 9.18,8.98$, and 8.88 (Fig. 4). The slow-exchange spectrum obtained at $-80{ }^{\circ} \mathrm{C}$ is consistent with the solid-state structure, where the three aldehyde groups are inequivalent. A dynamic process by exchange of the $\mathrm{Cu}$-aldehyde interaction may account for the spectra observed. The existence of a $\mathrm{Cu} \cdots \mathrm{O}$ interaction in solution is supported by the IR spectrum in $\mathrm{CH}_{2} \mathrm{Cl}_{2}$, which displays two $\mathrm{C}=\mathrm{O}$ stretching bands at 1698 and $1675 \mathrm{~cm}^{-1}$ in an approximate 1:2 ratio. On the other hand, the ${ }^{31} \mathrm{P}\left\{{ }^{1} \mathrm{H}\right\}$ NMR spectrum at $25^{\circ} \mathrm{C}$ shows one broad signal at $\delta 5.06$, while at $-80{ }^{\circ} \mathrm{C}$ it becomes a complicate multiplet in the range $\delta 6.36-3.01$, likely due to superimposed coupling between the inequivalent phosphorus nuclei and coupling to the ${ }^{63} \mathrm{Cu}(I=3 / 2$, $69 \%)$ and ${ }^{65} \mathrm{Cu}(I=3 / 2,31 \%)$ nuclei.

The ${ }^{1} \mathrm{H}$ NNR spectrum of 3 at $25{ }^{\circ} \mathrm{C}$ displays a $1 \mathrm{H}$ singlet at $\delta 9.65$ for the formyl proton, a multiplet between $\delta 7.70$ and 6.99 for the phenyl protons, and two $4 \mathrm{H}$ broad signals at $\delta 4.44$ and 4.22 for the Cp protons. The ${ }^{31} \mathrm{P}\left\{{ }^{1} \mathrm{H}\right\}$ NMR spectrum presents a triplet signal at

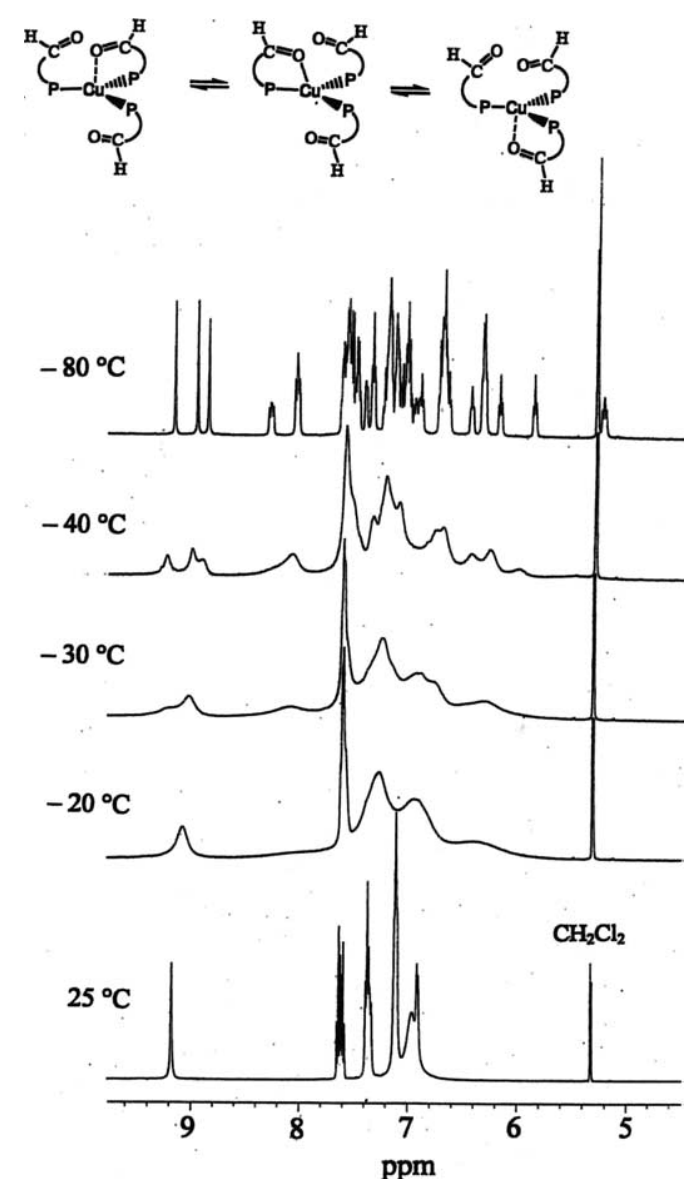

Fig. 4. Variable-temperature $500 \mathrm{MHz}{ }^{1} \mathrm{H}$ NMR spectra of 2 in $\mathrm{CD}_{2} \mathrm{Cl}_{2}$. $\delta 1.90$ and a doublet signal at $\delta-6.14\left({ }^{2} J_{\mathrm{P}-\mathrm{P}}=81 \mathrm{~Hz}\right)$ in an approximate 1:2 ratio for the $\mathrm{PCHO}$ and the DPPF ligands, respectively. The coordinated $\mathrm{C}=\mathrm{O}$ stretching frequency is recorded at $1663 \mathrm{~cm}^{-1}$ in $\mathrm{CH}_{2} \mathrm{Cl}_{2}$ solvent.

In conclusion, we have prepared three $\mathrm{Cu}(\mathrm{I})-\mathrm{PCHO}$ complexes with/without the chelation of formyl groups. The $\mathbf{C u}$-aldehyde interaction presented in $\mathbf{2}$ is apparently arising from overlap of the carbonyl lone pair with the empty $\mathrm{Cu} \mathrm{p}_{z}$-orbital (see below). One would expect some distortion of the trigonal-planar $\left(\mathrm{sp}^{2}\right)$ arrangement of the complex toward a trigonal-pyramidal $\left(\mathrm{sp}^{3}\right)$ arrangement in response to this donor-acceptor interaction, as observed for $\mathbf{2}$, whereas repulsions between the bulky phosphine groups prevent further distortion toward a tetrahedral arrangement. On the other hand, in 1 the copper atom is essentially lying on the basal trigonal plane, so its short $\mathrm{Cu} \cdots \mathrm{O}$ contact $(2.74 \AA)$ is better described as a consequence of packing constraints instead of bonding. Although complex $\mathbf{3}$ contains three phosphine ligands as $\mathbf{2}$, the confined $\mathrm{P}-\mathrm{Cu}-\mathrm{P}$ bite angle of DPPF ligand $\left(109.3^{\circ}\right)$ likely facilitates chelation of the formyl group to lead to a tetrahedral geometry. Finally, we note that the arrangement of formyl groups in $\mathbf{1}$ and 2 effectively blocks the access of the $\mathrm{BF}_{4}{ }^{-}$counterion to the $\mathrm{Cu}^{+}$ion, whereas the structures of $\left[\mathrm{Cu}\left(\mathrm{PPh}_{3}\right)_{3}\right]\left[\mathrm{BF}_{4}\right]$ [20] and $\left[\mathrm{Cu}\left(\mathrm{PPh}_{3}\right)_{3}\right]\left[\mathrm{FeCl}_{4}\right][21]$ reveal a weak coordination of the anion to the copper atom through one of its terminal halogen atoms.

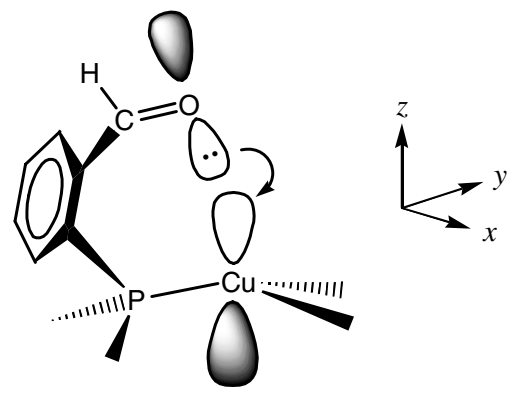

\section{Experimental}

\subsection{General methods}

All manipulations were carried out under an atmosphere of dinitrogen with standard Schlenk techniques. $\left[\mathrm{Cu}(\mathrm{NCMe})_{4}\right]\left[\mathrm{BF}_{4}\right]$ [22], $\mathrm{Ph}_{2} \mathrm{P}\left(o-\mathrm{C}_{6} \mathrm{H}_{4}\right) \mathrm{C}(=\mathrm{O}) \mathrm{H}$ (abbreviated as $\mathrm{PCHO}$ ) [3b], and $\left(\mathrm{Ph}_{2} \mathrm{PC}_{5} \mathrm{H}_{4}\right)_{2} \mathrm{Fe}$ (abbreviated as DPPF) [23] were prepared by the literature methods. 2,2'-bipyridine and 4,4'-bipyridine were purchased from Aldrich and used as received. Solvents were dried over appropriate reagents under dinitrogen and distilled 
immediately before use. ${ }^{1} \mathrm{H}$ and ${ }^{31} \mathrm{P}$ NMR spectra were obtained on a Varian Unity INOVA-500 spectrometer. Infrared spectra were recorded with a $0.1 \mathrm{~mm}$ path $\mathrm{CaF}_{2}$ solution cell on a Hitachi I-2001 IR spectrometer. Fast-atom-bombardment (FAB) mass spectra were recorded on a JEOL JMS-SX102A mass spectrometer. Elemental analyses were performed at the National Science Council Regional Instrumentation Center at $\mathrm{Na}$ tional Chen-Kung University, Tainan, Taiwan.

\subsection{Preparation of 1}

$\left[\mathrm{Cu}(\mathrm{NCMe})_{4}\right]\left[\mathrm{BF}_{4}\right](102 \mathrm{mg}, 0.325 \mathrm{mmol})$, acetonitrile $(1 \mathrm{ml})$ and dichloromethane $(10 \mathrm{ml})$ were placed in an oven-dried $50 \mathrm{ml}$ Schlenk flask, equipped with a magnetic stir bar and a rubber serum stopper. PCHO (190 mg, $0.65 \mathrm{mmol})$ in dichloromethane solvent $(5 \mathrm{ml})$ was then introduced into the flask and the mixture was stirred at room temperature for $16 \mathrm{~h}$, yielding a yellow solution. The solution was filtrated under dinitrogen and carefully layered with $n$-hexane $(20 \mathrm{ml})$. The airstable, yellow crystals of $\left[\mathrm{Cu}(\mathrm{PCHO})_{2}(\mathrm{NCMe})\right]\left[\mathrm{BF}_{4}\right]$ (1) $(214 \mathrm{mg}, 0.289 \mathrm{mmol})$ were obtained in $89 \%$ yield. Anal. Calc. for $\mathrm{C}_{40} \mathrm{H}_{33} \mathrm{BCuF}_{4} \mathrm{NO}_{2} \mathrm{P}_{2}: \mathrm{C}, 62.23 ; \mathrm{H}$, 4.31, N, 1.81. Found: C, 62.70; H, 4.51; N, 1.72\%. Mass (FAB): $m / z \quad 643 \quad\left(\mathrm{Cu}(\mathrm{PCHO})_{2}+;{ }^{63} \mathrm{Cu}\right) .{ }^{1} \mathrm{H} \quad \mathrm{NMR}$ $\left(\mathrm{CD}_{2} \mathrm{Cl}_{2}, 25{ }^{\circ} \mathrm{C}\right): \delta 9.74(\mathrm{~s}, 2 \mathrm{H}, \mathrm{CHO}), 7.97-7.03(\mathrm{~m}$, $28 \mathrm{H}, \mathrm{Ph}), 2.12$ (s, 3H, Me). ${ }^{31} \mathrm{P}\left\{{ }^{1} \mathrm{H}\right\}$ NMR $\left(\mathrm{CD}_{2} \mathrm{Cl}_{2}\right.$, $\left.25^{\circ} \mathrm{C}\right): \delta 0.47$ (s). IR $\left(\mathrm{CH}_{2} \mathrm{Cl}_{2}, \mathrm{~cm}^{-1}\right): 2284(\mathrm{C} \equiv \mathrm{N})$, $1670(\mathrm{C}=\mathrm{O})$.

\subsection{Preparation of $\mathbf{2}$ from 1}

Compound 1 (150 mg, $0.203 \mathrm{mmol})$ and dichloromethane $(5 \mathrm{ml})$ were placed in an oven-dried $50 \mathrm{ml}$ Schlenk flask. PCHO (59 mg, $0.203 \mathrm{mmol}$ ) in dichloromethane solvent $(5 \mathrm{ml})$ was then introduced into the flask and the mixture was stirred at room temperature for $12 \mathrm{~h}$, yielding an orange-yellow solution. The solution was filtrated under dinitrogen and then carefully layered with $n$-hexane $(20 \mathrm{ml}) . \quad\left[\mathrm{Cu}(\mathrm{PCHO})_{3}\right]\left[\mathrm{BF}_{4}\right]$ (2) $(185 \mathrm{mg}$, $0.187 \mathrm{mmol}, 92 \%$ ) was precipitated as an air-stable, orange-yellow crystalline solid. Anal. Calc. for $\mathrm{C}_{57} \mathrm{H}_{45} \mathrm{BCuF}_{4} \mathrm{O}_{3} \mathrm{P}_{3}: \mathrm{C}$, 67.04; $\mathrm{H}$, 4.44. Found: $\mathrm{C}$, 66.65; H, 4.49\%. Mass (FAB): $m / z 933\left(\mathrm{Cu}(\mathrm{PCHO})_{3}{ }^{+}\right.$; $\left.{ }^{63} \mathrm{Cu}\right) .{ }^{1} \mathrm{H}$ NMR $\left(\mathrm{CD}_{2} \mathrm{Cl}_{2}, 25{ }^{\circ} \mathrm{C}\right): \delta 9.17(\mathrm{~s}, 3 \mathrm{H}$, CHO), 7.74-7.56 (m, 6H), 7.42-7.25(m, 9H), 7.11-6.82 $(\mathrm{m}, 27 \mathrm{H}, \mathrm{Ph}) .{ }^{1} \mathrm{H}$ NMR $\left(\mathrm{CD}_{2} \mathrm{Cl}_{2},-80{ }^{\circ} \mathrm{C}\right): \delta 9.18(\mathrm{~s}$, $1 \mathrm{H}), 8.98(\mathrm{~s}, 1 \mathrm{H}), 8.88(\mathrm{~s}, 1 \mathrm{H}, \mathrm{CHO}), 8.33(\mathrm{~m}, 1 \mathrm{H})$, $8.05(\mathrm{~m}, 2 \mathrm{H}), 7.65-6.66(\mathrm{~m}, 32 \mathrm{H}), 6.45(\mathrm{~m}, 1 \mathrm{H}), 6.35$ $(\mathrm{m}, 3 \mathrm{H}), 6.19(\mathrm{~m}, 1 \mathrm{H}), 5.85(\mathrm{~m}, 1 \mathrm{H}), 5.21(\mathrm{~m}, 1 \mathrm{H}, \mathrm{Ph})$. ${ }^{31} \mathrm{P}\left\{{ }^{1} \mathrm{H}\right\}$ NMR: $\left(\mathrm{CD}_{2} \mathrm{Cl}_{2}, 25{ }^{\circ} \mathrm{C}\right) \delta 5.07(\mathrm{~s}) ;\left(\mathrm{CD}_{2} \mathrm{Cl}_{2}\right.$, $\left.-80{ }^{\circ} \mathrm{C}\right) \delta 6.36-3.01(\mathrm{~m})$. IR $\left(\mathrm{CH}_{2} \mathrm{Cl}_{2}, \mathrm{~cm}^{-1}\right): 1698 \mathrm{w}$, $1675 \mathrm{~m}(\mathrm{C}=\mathrm{O})$.

\subsection{Direct synthesis of 2 from $\left[\mathrm{Cu}(\mathrm{NCMe})_{4}\right]\left[\mathrm{BF}_{4}\right]$ and $\mathrm{PCHO}$}

$\left[\mathrm{Cu}(\mathrm{NCMe})_{4}\right]\left[\mathrm{BF}_{4}\right] \quad(105 \mathrm{mg}, \quad 0.335 \mathrm{mmol}), \quad \mathrm{PCHO}$ $(310 \mathrm{mg}, 1.07 \mathrm{mmol})$ and THF $(5 \mathrm{ml})$ were placed in an oven-dried $25 \mathrm{ml}$ Schlenk tube. The solution was refluxed for $40 \mathrm{~min}$ to afford an orange-yellow precipitate, characterized as compound 2 (298 $\mathrm{mg}, 90 \%)$.

\subsection{Preparation of $\mathbf{3}$}

Compound 1 (37 mg, $0.05 \mathrm{mmol}$ ), DPPF (28 mg, $0.05 \mathrm{mmol})$ and THF $(5 \mathrm{ml})$ were placed in an ovendried $25 \mathrm{ml}$ Schlenk tube. The solution was refluxed for $40 \mathrm{~min}$, cooled to ambient temperature, and carefully layered with $n$-hexane. [Cu(PCHO)(DPPF)] $\left[\mathrm{BF}_{4}\right]$ (3) $(28 \mathrm{mg}, 0.028 \mathrm{mmol}, 56 \%)$ was obtained as air-stable,

Table 1

Crystallographic data for $\mathbf{1}-\mathbf{3}$

\begin{tabular}{llll}
\hline & $\mathbf{1}$ & $\mathbf{2}$ & $\mathbf{3}$ \\
\hline Formula & $\mathrm{C}_{40} \mathrm{H}_{33} \mathrm{BCuF}_{4} \mathrm{NO}_{2} \mathrm{P}_{2}$ & $\mathrm{C}_{53} \mathrm{H}_{43} \mathrm{BCuF}_{4} \mathrm{FeOP}_{3}$ \\
Crystal solvent & $0.5 \mathrm{Et}_{2} \mathrm{O}$ & $\mathrm{C}_{57} \mathrm{H}_{45} \mathrm{BCuF}_{4} \mathrm{O}_{3} \mathrm{P}_{3}$ & $2 \mathrm{CH}_{2} \mathrm{Cl}_{2}$ \\
Crystal system & monoclinic & triclinic & triclinic \\
Formula weight & 809.02 & 1191.04 & 994.98 \\
$T(\mathrm{~K})$ & 150 & 150 & 150 \\
Space group & $P 2{ }_{1} / c$ & $P \overline{1}$ & $P \overline{1}$ \\
$A(\AA)$ & $8.3108(4)$ & $12.496(1)$ & $10.4768(7)$ \\
$b(\AA)$ & $25.293(1)$ & $15.454(1)$ & $14.0088(9)$ \\
$c(\AA)$ & $18.4483(9)$ & $15.693(1)$ & $15.949(1)$ \\
$\alpha\left({ }^{\circ}\right)$ & 90 & $69.724(2)$ & $93.405(1)$ \\
$\beta\left({ }^{\circ}\right)$ & $93.634(1)$ & $88.827(2)$ & $93.115(1)$ \\
$\gamma\left({ }^{\circ}\right)$ & 90 & $76.487(2)$ & $108.539(1)$ \\
$V\left(\AA^{3}\right)$ & $3870.1(3)$ & $2754.5(4)$ & $2208.8(2)$ \\
$Z$ & 4 & 2 & 2 \\
$D_{\text {calc }}\left(\mathrm{Mg} / \mathrm{m}^{3}\right)$ & 1.389 & 1.436 & 1.496 \\
$\left.\mu(\mathrm{mm})^{-1}\right)$ & 0.705 & 0.736 & 0.976 \\
Final $R$ indices $(I>2 \sigma(I))$ & $0.0746 / 0.1650$ & $0.0879 / 0.1997$ & $0.0390 / 0.0977$ \\
Goodness-of-fit on $F^{2}$ & 1.176 & 1.020 & 1.057 \\
\hline
\end{tabular}


orange crystals. Anal. Calc. for $\mathrm{C}_{53} \mathrm{H}_{43} \mathrm{BF}_{4} \mathrm{FeOP}_{3} \mathrm{Cu}$ : C, 63.97; H, 4.36. Found: C, 63.50; H, 4.45\%. Mass (FAB): $\mathrm{m} / \mathrm{z} 907\left(\mathrm{Cu}(\mathrm{PCHO})(\mathrm{DPPF}){ }^{+} ;{ }^{63} \mathrm{Cu}\right) .{ }^{1} \mathrm{H} \mathrm{NMR}\left(\mathrm{CDCl}_{3}\right.$, $\left.25{ }^{\circ} \mathrm{C}\right): \delta 9.65$ (s, 1H, CHO), 7.70-6.99 (m, Ph), 4.44 (br, $4 \mathrm{H}), 4.22$ (br, $\left.4 \mathrm{H}, \mathrm{C}_{5} \mathrm{H}_{4}\right) .{ }^{31} \mathrm{P}\left\{{ }^{1} \mathrm{H}\right\}$ NMR $\left(\mathrm{CDCl}_{3}, 25\right.$ $\left.{ }^{\circ} \mathrm{C}\right): \delta 1.90\left(\mathrm{t}, \mathrm{PCHO},{ }^{2} J_{\mathrm{P}-\mathrm{P}}=81 \mathrm{~Hz}\right),-6.14(\mathrm{~d}, \mathrm{DPPF})$. IR $\left(\mathrm{CH}_{2} \mathrm{Cl}_{2}, \mathrm{~cm}^{-1}\right)$ : $1663(\mathrm{C}=\mathrm{O})$.

\subsection{Structure determination for 1-3}

The crystals of 1, 2 and 3 found suitable for X-ray analysis were each mounted in a thin-walled glass capillary and aligned on the Bruker Smart ApexCCD diffractometer, with graphite-monochromated Mo $\mathrm{K} \alpha$ radiation $(\lambda=0.71073 \AA)$. The $\theta$ range for data collection is $1.37-25.00^{\circ}$ for $1,1.39-25.00^{\circ}$ for $\mathbf{2}$, and 1.28 $27.50^{\circ}$ for 3 . Of the 30852,29598 and 28408 reflections collected for 1, $\mathbf{2}$ and 3, 6805, 9704, and 10104 reflections were independent, respectively. All data were corrected for Lorentz and polarization effects and for the effects of absorption. The structure was solved by the direct method and refined by least-square cycles. The nonhydrogen atoms were refined anisotropically. Hydrogen atoms were included but not refined. All calculations were performed using the SHELXTL-97 package [24]. The data collection and refinement parameters are presented in Table 1.

\section{Acknowledgment}

We are grateful for support of this work by the National Science Council of Taiwan.

\section{Appendix A. Supplementary material}

Crystallographic data for 1-3 have been deposited with the Cambridge Crystallographic Data Centre, deposition numbers CCDC 249800-249802. Copies of these data may be obtained free of charge from The Director, CCDC, 12 Union Road, Cambridge CB2 1EZ, UK. Supplementary data associated with this article can be found, in the online version at doi:10.1016/ j.ica.2004.12.049.

\section{References}

[1] (a) B.J. Hathaway, in: Comprehensive Coordination Chemistry, vol. 5, Pergamon, Oxford, UK, 1987, p. 533;

(b) D.R. Smith, Coord. Chem. Rev. 172 (1998) 457;

(c) R. Mukherjee, in: Comprehensive Coordination Chemistry II, vol. 6, Elsevier, Oxford, UK, 2004, p. 747; (d) M.A. Carvajal, J.J. Novoa, S. Alvarez, J. Am. Chem. Soc. 126 (2004) 1465 .

[2] (a) H.-F. Klein, A. Bickelhaupt, T. Jung, G. Cordier, Organometallics 13 (1994) 2557;

(b) J.-C. Hierso, R. Amardeil, E. Bentabet, R. Broussier, B. Gautheron, P. Meunier, P. Kalck, Coord. Chem. Rev. 236 (2003) 143;

(c) P. Braunstein, J. Durand, M. Knorr, C. Strohmann, Chem. Commun. (2001) 211;

(d) G.R. Newkome, Chem. Rev. 93 (1993) 2067;

(e) V.J. Catelano, B.L. Bennett, S. Muratidis, B.C. Noll, J. Am. Chem. Soc. 123 (2001) 173.

[3] (a) G.P. Schiemenz, H. Kaack, Justus Liebigs Ann. Chem. (1973) 1480 ;

(b) J.E. Hoots, T.B. Rauchfuss, D.A. Wrobleski, Inorg. Synth. 21 (1982) 175.

[4] E.W. Ainscough, A.M. Brodie, S.L. Ingham, J.M. Waters, Inorg. Chim. Acta 234 (1995) 163.

[5] R. El Mail, M.A. Garralda, R. Hernández, L. Ibarlucea, J. Organomet. Chem. 648 (2002) 149.

[6] (a) C. Bianchini, A. Meli, M. Peruzzini, J.A. Ramirez, A. Vacca, F. Vizza, F. Zanobini, Organometallics 8 (1989) 337;

(b) R. El Mail, M.A. Garralda, R. Hernández, L. Ibarlucea, E. Pinilla, M.R. Torres, Organometallics 19 (2000) 5310 ;

(c) R. El Mail, M.A. Garralda, R. Hernández, L. Ibarlucea, E. Pinilla, M.R. Torres, Helv. Chim. Acta 85 (2002) 1485.

[7] (a) E.F. Landvatter, T.B. Rauchfuss, Organometallics 1 (1982) 506;

(b) M.A. Garralda, R. Hernández, L. Ibarlucea, E. Pinilla, M.R. Torres, Organometallics 22 (2003) 3600.

[8] (a) J.J. Koh, W.H. Lee, P.G. Williard, W.M. Risen, J. Organomet. Chem. 284 (1985) 409;

(b) C.A. Ghilardi, S. Midollini, S. Moneti, A. Orlandini, J. Chem. Soc., Dalton Trans. (1988) 1833.

[9] H.F. Klein, U. Lemke, M. Lemke, A. Brand, Organometallics 17 (1998) 4196.

[10] S.E. Watkins, D.C. Craig, S.B. Colbran, Inorg. Chim. Acta 307 (2000) 134.

[11] P. Crochet, M.A. Fernández-Zumel, C. Beauquis, J. Gimeno, Inorg. Chim. Acta 356 (2003) 114.

[12] X. Chen, F.J. Femia, J.W. Babich, J. Zubieta, Inorg. Chim. Acta 315 (2001) 147.

[13] T.B. Rauchfuss, J. Am. Chem. Soc. 101 (1979) 1045

[14] C.P. Lenges, M. Brookhart, P.S. White, Angew. Chem., Int. Ed. 38 (1999) 552.

[15] W.-Y. Yeh, C.-S. Lin, S.-M. Peng, G.-H. Lee, Organometallics 23 (2004) 917.

[16] A. Baiada, F.H. Jardine, R.D. Willett, K. Emerson, Inorg. Chem. 30 (1991) 1365.

[17] A.H. Levin, R.J. Michl, P. Garis, U. Lepore, J. Chem. Soc., Chem. Commun. (1972) 661.

[18] I. Csoregh, P. Kierkegaard, R. Norrestam, Acta Crystallogr., Sect. B 31 (1975) 314.

[19] F.A. Cotton, G. Wilkinson, Advanced Inorganic Chemistry, fifth ed., Wiley, New York, 1988.

[20] A.P. Gaughan, Z. Dori, J.A. Ibers, Inorg. Chem. 7 (1974) 1657.

[21] D.J. Saturnino, A.M. Arif, Inorg. Chem. 32 (1993) 4157.

[22] G.J. Kubas, Inorg. Synth. 19 (1979) 90.

[23] I.R. Butler, in: Inorganic Experiments, VCH, Weinheim, Germany, 1994.

[24] G.M. Sheldrick, shelXTL-97, University of Göttingen, Germany, 1997. 